\title{
ОРГАНІЗАЦІЙНО-ПРАВОВЕ РЕГУЛЮВАННЯ ВЗАЄМОДІЇ СУБ'ЄКТІВ ІНВЕСТИЦІЙНОЇ ДІЯЛЬНОСТІ СФЕРИ ТУРИЗМУ ДЛЯ ОБ'ЄДНАНИХ ТЕРИТОРІАЛЬНИХ ГРОМАД
}

\author{
Смовженко Тамара степанівна \\ доктор економічних наук, професор \\ ДВНЗ «Університет банківської справи», (м. Київ, Україна) \\ ORCID 0000-0002-1534-9921 \\ ubs@ubs.gov.ua \\ Коркуна Орислава Іванівна \\ кандидат економічних наук, доцент \\ Львівський державний університет фізичної культури імені І. Боберського (м. Львів, Україна) \\ ORCID 0000-0002-8134-3771 \\ grafskayaorislava@gmail.com \\ Кулик Оксана Михайлівна \\ студентка факультету туризму \\ Львівський державний університет фізичної культури імені І. Боберського (м. Львів, Україна), \\ ORCID 0000-0003-4218-1658 \\ grafskayaorislava@gmail.com
}

У статті проаналізована організовано-правова система правового регулювання взаємодії суб'єктів інвестиційної діяльності сфрери туризму для об'єднаних територіальних громад. Досліджено та охарактеризовано основні нормативноправові документи, які забезпечують правові взаємовідносини між суб'єктами інвестиційної діяльності. Визначено вплив держави на інвестиційний процес..

Ключові слова: об'єднана територіальна громада, інвестиції, інвестиційні проекти, організаційно-правове регулювання, сфрера туризму.

DOl: https://doi.org/10.32845/bsnau.2019.4.28

Постановка проблеми. Сьогодні інвестиційна привабливість України значною мірою залежить від макро і мікропоказників та від її іміджу на міжнародному ринку. Мова іде про систему моніторингу з боку держави для забезпечення реального ефективного дієвого механізму дотримання законодавчо-нормативної бази щодо прав інвесторів на території України. Актуальним питанням для сфери туризму, яка активно розвивається в об'єднаних територіальних громадах (ОТГ) є впровадження інвестиційних та інноваційних проектів. Для забезпечення позитивного розвитку та впровадження цих проектів, необхідна правильно побудована концепцію роботи в цьому напряму, а це можливо тільки за сприятливих умов з боку нормативного-правового забезпечення.

Аналіз останніх досліджень і публікацій. Проблеми нормативно-правового регулювання і інвестиційної діяльності досліджувалися багатьма науковцями. Системні дослідження беруть свій початок у працях А. Сміта, Д. Рікардо, Дж. Мілля. Розвиток їх ідей міститься у працях К. Маркса, А. Маршалла, Й. Шумпетера, І. Фішера. Сьогодні проблема інвестиційної діяльності у сфері туризму для ОТГ досліджується вітчизняними вченими серед яких Б. Адамик, М. Біль [1], О. Луцків [2], 3. Сірик [3, 4], П. Жук [5], М. Мельник [5], Л. Созанський, І. Сторонянська, Н. Попадинець [6], А. Пересада [7] та ін. Однак у цих дослідженнях мало уваги приділено нормативно-правовому регулюванню інвестиційної діяльності в об'єднаних територіальних громадах.

Метою статті є дослідження процесу взаємодії суб'єктів інвестиційної діяльності сфери туризму для об'єднаних територіальних громад.

Виклад основного матеріалу. Туризм в Україні на сьогоднішній день один з самих прибуткових сфер діяльності, а для ново утворених територіальних громад, це вагома частка внеску у місцевий бюджет. Туризм вважається важливим джерелом доходу до бюджету не тільки ОТГ а й бюджету держави загалом. Туризм в себе включає дуже багато різних сфер, та секторів економіки, і за рахунок цього дуже важко зробити точний аналіз даних скільки працездатного населення зайнято в цій галузі. Робота в туристичній сфері характеризується різними відмінностями, це розумова праця, фізична праця, організаторська праця, робота по залученню клієнтів в дану сферу послуг та інше. Але головна функція всіх зайнятих в сфері туризму, це організація та продаж туристичних послуг клієнтам з митою отримання максимального прибутку, а відповідно від отриманого прибутку підприємства туристичної ссрери сплачують податок, який і $є$ дохідною частиною бюджету як на місцевому, регіональному так і державному рівні.

Туризм загалом дуже позитивно впливає на розвиток економіки регіону, а загалом на розвиток територіальних громад, як показує статистика в сфері туризму на сьогоднішній день зайнято більше $50 \%$ працездатного населення. Також позитивний вплив туризму на розвиток територіальних громад та регіону загалом пов'язано з тим, що витрати туристів трансформуються у вклади в економіку певної території, це відбувається за рахунок надання різних готельно-ресторанних послуг, послуг екскурсоводів, аніматорів та купівлі продажу різних товарів. Позитивним фрактором діяльності туристичної ссрери вважається той фактор коли сума ввезеної туристами валюти в регіон переважає суму валюти, яку вивезли з регіону. Також прямив фрактором впливу туристичної сфрери на економіку територіальних громад та регіону можна вважати використання частини доходів туристів на покупки ними 
товарів та послуг. Крім прямого впливу туризму на територіальні громади та на регіон існують ще і непрямий вплив. До непрямого впливу ми можемо віднести дію «ефект мультиплікатора», який діє в міру розширення туризму в регіоні. Ця дія пояснюється наступним: групи іноземних туристів подорожуючи, витрачають чи малу суму на купівлю товарів та послуг, а дохід туристичних підприємств - це виключно їх виручка від продажу послуг, а решту це іде як додаткові надходження, через сплату податків супутніми підприємствами від отриманого доходу. Тобто зав'язується так званий «ланцюг послуг», але все це і формує дохід територіальної громади, регіону та держави загалом. Всі витрачені кошти туристами крім того, що дають дохід підприємствам сфери туризму, та заробітної плати працівникам вони починають працювати на розвиток економіки певної територіальної громади.

Тому аналізуючи важливу роль туризму для економіки ОТГ, економіки регіону та економіки держави, можна зробити висновок, що для безперебійного функціонування даної сфери необхідним є залучення, як вітчизняних так і іноземних інвесторів, для створення відповідного колориту туристичних послуг. Зрозумілим є те, що без правильного організаційноправового регулювання в даній сфері не обійтися, тому від прийнятих законів України, постанов і указів, у сфері інвестиційної діяльності та податкового навантаження залежить можливість та перспектива залучення інвесторів для розвитку туристичного бізнесу, як регіоні та і державі загалом.

В умовах транзитивної економіки соціальна та демографрічна складові потребують першочергового вирішення багатьох питань. Більшість населення в Україні живе за межею бідності, що було визнано і парламентом, і урядом, i, на жаль, процес поглиблюється. Від платоспроможності та економічних свобод населення залежить інвестиційна активність підприємств в різні сфери діяльності, а зокрема і в сферу туризму. Соціальні чинники прямо впливають на попит та можливості суб'єктів господарювання реалізувати продукцію, роботи та послуги. Значне розшарування верств населення та розрив у розмірах заробітної плати (мінімальна та максимальна) негативно впливають на інвестиційне макросередовище в Україні. Відсутність ефективної пенсійної, соціальної систем захисту та медичної допомоги унеможливлюють зростання іміджу країни на сучасному етапі. Покращення інвестиційного середовища та соціальної системи захисту населення повинні здійснюватись паралельно, бо це дві складові одного процесу підвищення рівня задоволення потреб виробників товарів та послуг та їх споживачів. Кожна окрема система потребує не тільки наявних відповідних складових, які були розглянуті раніше, а також відповідної інфраструктури, яка могла б вирішувати питання щодо поліпшення інвестиційного середовища України на сучасному етапі розвитку нашої країни. Ці структури мають формувати відповідні стратегії, систему організаційно-правового регулювання на державному рівні з відповідними підсистемами. Вибір способу освоєння інвестицій залежить від виду реалізованого інвестиційного проекту, джерел його фрінансування, та бажання інвестора [2]..

В ринкових умовах державне регулювання інвестиційного процесу зводиться до захисту інтересів споживача інвестиційних коштів шляхом використання податкових і фінансово-кредитних важелів, за допомогою ліцензування, станда- ртизації і нормування, застосування екологічного і санітарного контролю, антимонопольних мір. Усі ці міри повинні враховувати суб'єкти інвестиційної діяльності, вступаючи в договірні відносини з інвестором. Взаємини між суб'єктами інвестиційної діяльності та інвестором регулюються договором. В договорах чітко прописується, ціль та мета, а також бачення дохідної частини від даного інвестиційного проекту, та розподіл чистого прибутку після завершення інвестиційного вкладення інвестором. Усе це описується у договорах про співпрацю, меморандумах та інших документах, на підставі яких починається реалізація інвестиційного проекту.

Найбільш поширеним документом для початку здійснення інвестиційної діяльності є договір. Договірна документація, як правило, складається з договору і додатків, у яких приводяться необхідні пояснення, обґрунтування і розрахунки, та технічна документація. Договір містить загальні, додаткові й особливі умови. Загальні умови - це типові, незмінні для усіх випадків вимоги, установлювані чинним законодавством. Також в договорах обов'язково прописується форсмажорна ситуація на випадок надзвичайних ситуацій, війна, чи епідемія. Додаткові умови передбачають предмет конкретного договору, що склалася практику договірних відносин конкретного інвестора і об'єкта куди інвестор вкладає свої інвестиції. Додаткові умови не можуть суперечити загальним. Додаткові умови договору включають спеціальні вимоги, що обумовлюються в конкретному договорі. Звичайно особливими умовами обмовляються гарантії розподілу ризику при непередбачених обставинах, процедури вирішення можливих суперечок. Особливі умови - це також умови про створення консорціуму між інвестором та об'єктом інвестування.

Також невід'ємною часткою укладання інвестиційних договорі на сьогоднішній день, є страхові договори.

Інвестиційна діяльність і страхування - тісне взаємозалежні категорії ринкової економіки. Інвестиції, особливо довгострокові, підпадають під різного роду ризики, несподіваними небезпеками, що можуть підстерігати інвестора. Тому вкладення інвестиційного капіталу на тривалий термін завжди забезпечується оцінними розрахунками всіляких ризиків і обов'язково страхується і перестраховується [3].

Практика минулих років страхування інвестицій усе частіше стає не тільки методом огородження вкладень від руйнівних стихійних лих, але і засобом захисту від несприятливої зміни економічної кон'юнктури. У цих умовах інвестор зобов'язаний частину свого коштів заплати за страховий платіж, який в майбутньому, може забезпечити його від втрати основного інвестиційного капіталу. Для інвестора, що виступає як страхувальник, особливо важливо знати умови страхування інвестиційної діяльності, реальні виплати з метою відшкодування можливих збитків щоб уникнути невигідних договорів страхування такого об'єкта як інвестиційні операції. Страхування інвестиційних проектів передбачає відшкодування інвестору можливих утрат за умови, що через визначений термін застраховані інвестиції не забезпечать очікуваного доходу.

Розмір страхового відшкодування встановлюється як різниця між страховою сумою і реальними результатами інвестиційної діяльності. Ціль страхування складається в захисті страхувальника (інвестора) від можливих збитків в інвестиційній діяльності чи втрат інвестиції, тому договір страхування, як правило, полягає на термін, що відповідає періоду 
окупності інвестиційного капіталу.

Особливості страхування інвестиційних проектів та інвесторів включають в себе додаткові вимоги при укладені договорів страхування :

- наявність у страхувальника дозволу (ліцензії чи патенту) на здійснення визначеного виду діяльності якщо ми говоримо про туристичну сферу, для прикладу (для будівництва готельного комплексу );

- обов'язковий додаток до заяви інвестора про страхування інформації, що дозволяє судити про ступінь ризику інвестування в кожнім конкретному випадку (умови інвестиційної діяльності, надійність її суб'єктів, передбачувані доходи і витрати, та форс-мажорні умови, які підлягають для забезпечення страховим виплатам [7].

Договір страхування може також покладати обов'язки на страхувальника повідомляти страховій фірмі, у міру зміни умов інвестиційної діяльності, можливі зміни в ступені страхового ризику, уникати дій, що підвищують цей ризик. Можливі окремі обмеження по наданню послуг страхування, а також у страховій відповідальності, з якої звичайно виключаються, зокрема, збитки через воєнні дії, політичної нестабільності, рішень державних органів, зміни валютних курсів, законодавства, збиток від відмовлення банку в наданні кредитних засобів. Не підлягають відшкодуванню збитки внаслідок навмисних дій страхувальника по створенню перешкод для успішної інвестиційної чи діяльності порушення діючого законодавства. Інвестор повинний знати, що страхова компанія може довільно встановлювати і переглядати перелік ризиків, що підлягають страхуванню. Специсріка страхування інвестицій полягає в тому, що відшкодування понесеного збитку здійснюється переважно після закінчення терміну страхування 3 урахуванням реальних результатів інвестиційної діяльності. Тому при визначенні терміну дії договору страхування необхідно враховувати наявний вітчизняний досвід, наукові і практичні рекомендації, усілякі дані про окупність витрат по окремих інвестиційних проектах як вітчизняним, так і іноземним інвесторам.

Варто розрізняти повний провал інвестиційної діяльності, що підлягає страховому відшкодуванню, і різного роду тимчасові утруднення (зокрема, зв'язані зі зміною кон'юнктури ринку), що згодом можуть бути переборені інвестором. Тому, як правило, тільки по завершенні повного комплексу інвестиційних операцій можна зробити остаточний висновок про фінансові підсумки інвестиційної діяльності і надання страхувальнику компенсаційних виплат відповідно до договору страхування [5].

Страхування інвестицій передбачає встановлення мінімальної франчизи, тобто неоплачуваної частини збитку, чи надання інвестору права ії̈ збільшувати. Франчиза може бути умовної і безумовний. Договір страхування може встановлювати також обмеження верхньої межі компенсації збитку у відсотках до загальної суми. Для кожного інвестиційного проекту характерні специфічні ризики, тому страхові фірми диференціюють ставки платежів, що залежать від сукупності умов, зокрема, від виду інвестиційної діяльності, тривалості терміну страхування, стабільності політичної й економічної ситуації й iH.

Страхування інвестиції виробляється в залежності від об'єкта інвестування і рівня ризиків. Для інвестора можна виділити наступні найбільш важливі об'єкти страхування:

- вкладення в оборотні кошти;

- вкладення в основні виробничі фонди;

- інвестиції в нову техніку і технологію.

Висновки. Виходячи з наведеного, можна зробити висновок, що залучення як вітчизняних, так і іноземних інвесторів в Україну для розвитку ОТГ, розвитку регіонів та держави в цілому $є$ дуже важливим і актуальним питанням на сьогоднішній день. Динамічне здійснення інвестиційної діяльності $€$ необхідною умовою для забезпечення стійкого економічного зростання в всіх ссрерах економіки України загалом та сфрері туризму зокрема це створення нових робочих місць, сплата податків до бюджетів місцевих і регіональних рівнів, та покращення добробуту населення та інфрраструктури регіону Невід'ємною складовою сприятливого інвестиційного клімату є належне правове регулювання інвестиційних відносин на засадах збалансування приватних інтересів інвесторів щодо отримання бажаної віддачі від капіталовкладень. Потреба суттєвого удосконалення правового забезпечення інвестиційної діяльності в Україні в сфері туризму очевидна, зокрема, з огляду на хронічне недофінансування з боку держави, та неможливості підтримки вітчизняних інвесторів на регіональному рівні. Попри надзвичайну різноманітність інвестиційних відносин, їх успішне регулювання вимагає формування у низки законів та законопроектів та втілення їх у державній інвестиційній політиці цілісно, для успішного здійснення інвестиційно-правового регулювання.

\section{Список використаної літератури:}

1. Біль М. М., Лещух І. В., Попадинець Н. М. Наукові засади дослідження ендогенного потенціалу територіальних громад. Інфраструктура ринку : наук.-практ. журн. Вип. 26. Одеса. 2018. URL : http://www.market-infr.od.ua/uk

2. Луцків О. М., Попадинець Н.М. Проблеми інституційно-організаційного забезпечення інвестиційно-інноваційного розвитку у регіоні. Соціально-економічні проблеми сучасного періоду України. 2019. Вип. 1(135). С. 33-37.

3. Сірик 3. О. Місцеве самоврядування та інвестиційні процеси : європейські процеси та вітчизняні реалії. Ефективність державного управління. 2016. №4(49). С. 266-274.

4. Сірик 3. О. Ендогенні чинники активізації використання інвестиційно-інноваційного потенціалу громад. Соціально-економічні проблеми сучасного періоду України. 2018. №4(132). С.134-147.

5. Жук П.В., Сірик 3.О. Інвестиційний потенціал територіальних громад : суть поняття та питання управління. Регіональна економіка. 2017. №2, С. 16-22.

6. Melnyk M., Korcelli-Olejniczak E., Chorna N., Popadynets N. Development of Regional IT clusters in Ukraine: institutional and investment dimensions. Economic Annals-XXI. 2018. № 173(9-10). Pp. 19-25.

7. Попадинець Н.М. Структурні зміни в економіці Івано-Франківської області : інвестиційний вплив. Проблеми формування та розвитку інноваційної інфраструктури: європейський вектор - нові виклики та можливості: тези доповідей III Міжнародної науково-практичної конференції. Львів: Видавництво Львівської політехніки, 2015. С. 552-553. 
8. Пересада А. А. Основи інвестиційної діяльності. - К.: Вид-во “Лібра ООО”, 2000.

\section{References:}

1. Bil, M.M., Leshchukh, I.V., Popadynets, N. M. (2018). Naukovi zasady doslidzhennya endohennoho potentsialu terytorial'nykh hromad [Scientific foundations of the research of territorial communities' endogenous potential]. Infrastruktura rynku Market Infrastructure, 26. URL : http://www.market-infr.od.ua/uk

2. Lutskiv, O., Popadynets, N. (2019). Problemy instytutsiyno-orhanizatsiynoho zabezpechennya investytsiyno-innovatsiynoho rozvytku $v$ rehioni [Problems of institutional-organizational maintenance of investment-innovative development in a region]. Sotsial'no-ekonomichni problemy suchasnoho periodu Ukrayiny - Socio-Economic Problems of the Modern Period of Ukraine. 135(1), 33-37. DOI: https://doi.org/10.36818/2071-4653-2019-1-7

3. Siryk, Z. (2016). Mistseve samovryaduvannya ta investytsiyni protsesy : yevropeys'ki protsesy ta vitchyznyani realiyi [Local self-governance and investment processes: European processes and domestic realities]. Efektyvnist' derzhavnoho upravlinnya - Efficiency of public administration, 4(49), 266-274.

4. Siryk, Z. (2018). Endohenni chynnyky aktyvizatsiyi vykorystannya investytsiyno-innovatsiynoho potentsialu terytorial'nykh hromad [Endogenous factors of activating the use of investment and innovation potential of territorial communities]. Sotsial'noekonomichni problemy suchasnoho periodu Ukrayiny - Socio-Economic Problems of the Modern Period of Ukraine. 132 (4), $125-133$.

5. Zhuk, P. V., Siryk, Z. O. (2017). Investytsiynyy potentsial terytorial'nykh hromad: sut' ponyattya ta pytannya upravlinnya [Investment capacity of territorial communities: nature of the concept and management issues]. Rehional'na ekonomika - Regional Economy, 84(2), 16-22.

6. Melnyk, M., Korcelli-Olejniczak, E., Chorna, N., Popadynets, N. (2018). Development of Regional IT clusters in Ukraine: institutional and investment dimensions. Economic Annals-XXI. 173(9-10), 19-25.

7. Popadynets, N. M. (2015). Strukturni zminy v ekonomitsi Ivano-Frankivs'koyi oblasti : investytsiynyy vplyv [Structural changes in the economy of Ivano-Frankivsk region: investment impact]. Problems of formation and development of innovation infrastructure: European vector - new challenges and opportunities: abstracts of reports of the III International scientific-practical conference. Lviv: Lviv Polytechnic Publishing House, 552-553.

8. Peresada, A. A. (2000). Osnovy investytsiynoyi diyal'nosti [Fundamentals of investment activity]. Kyiv: Libra Ltd. Publishing House.

Smovzhenko Tamara Stepanivna, Dr. Professor, University of Banking (Kyiv, Ukraine)

Korkuna Oryslava Ivanivna, PhD, Associate Professor of the Department of hotel restaurant business of the Lviv State University of Physical Culture n.a. Ivan Bobersky (Lviv, Ukraine) Ukraine)

Kulyk Oksana Mykhaylivna, student of the Faculty of Tourism I. Boberskyi Lviv State University of Physical Culture (Lviv,

Organizational and legal regulation of interaction between subjects of investment activity and united territorial communities in the sphere of tourism

Today, Ukraine's investment attractiveness largely depends on macro and micro indicators and its image in the international market. It is a system of monitoring by the state to ensure a real effective mechanism for compliance with the legal framework for the rights of investors in Ukraine. The implementation of investment and innovation projects is a topical issue for the sphere of tourism, which is actively developing in the united territorial communities. To ensure the positive development and implementation of these projects, it is necessary to properly construct the concept of work in this direction, and this is possible only under favorable conditions of the regulatory framework. The article analyzes the organized legal system of the interaction of investment entities in the sphere of tourism for the united territorial communities. The basic normative-legal documents which provide legal mutual relations between subjects of investment activity are investigated and characterized. The influence of the state on the investment process is determined. It is proved that the dynamic implementation of investment activities is a necessary condition for sustainable economic growth in all sectors of Ukraine's economy in general and tourism in particular, as it creates new jobs, pays taxes to local and regional budgets, and improves welfare and community infrastructure. It is established that an integral part of a favorable investment climate is the proper legal regulation of investment relations on the basis of balancing private interests, investors to obtain the desired return on investment. It is determined that despite the extraordinary diversity of investment relations, their successful regulation requires the formation of a number of draft amendments and their implementation in public investment policy as a whole, for the successful implementation of investment regulation at the state level and united territorial communities.

Key words: united territorial community, investments, investment projects, organizational and legal regulation, sphere of tourism.

Дата надходження до редакції: 12.11.2019 р. 